\title{
OPEN Early production of table olives at a mid-7th millennium BP submerged site off the Carmel coast (Israel)
}

E. Galili1,2,3凶 D. Langgut ${ }^{4}$, J. F. Terral ${ }^{5,6}$, O. Barazani ${ }^{7}$, A. Dag ${ }^{8}$, L. Kolska Horwitz ${ }^{9}$, I. Ogloblin Ramirez ${ }^{3}$, B. Rosen ${ }^{10}$, M. Weinstein-Evron ${ }^{11}$, S. Chaim ${ }^{11}$, E. Kremer ${ }^{4}$, S. Lev-Yadun ${ }^{12}$, E. Boaretto ${ }^{13}$, Z. Ben-Barak-Zelas ${ }^{14}$ \& A. Fishman ${ }^{14}$

We present here the earliest evidence for large-scale table olive production from the mid- $7^{\text {th }}$ millennium BP inundated site of Hishuley Carmel on the northern Mediterranean coast of Israel. Olive pit size and fragmentation patterns, pollen as well as the architecture of installations associated with pits from this site, were compared to finds from the nearby and slightly earlier submerged Kfar Samir site. Results indicate that at Kfar Samir olive oil was extracted, while at Hishuley Carmel the data showed that large quantities of table olives, the oldest reported to date, were prepared. This process was most probably facilitated by the site's proximity to the Mediterranean Sea, which served as a source of both sea water and salt required for debittering/pickling/salting the fruit, as experimentally demonstrated in this study. Comparison of pit morphometry from modern cultivars, wild-growing trees and the archaeological sites, intimates that in pit morphology the ancient pits resemble wild olives, but we cannot totally exclude the possibility that they derive from early cultivated trees. Our findings demonstrate that in this region, olive oil production may have predated table olive preparation, with each development serving as a milestone in the early exploitation of the olive.

Throughout the Mediterranean Basin, the olive tree is considered an emblematic and economically important species (e.g. ${ }^{1-3}$ ). The domesticated form (Olea europaea subsp. europaea var. sativa), commonly known as Olea europaea, has given rise to hundreds of cultivars in different geographic areas ${ }^{4,5}$. Its main wild progenitor, commonly known as oleaster (O. europaea subsp. europaea var. sylvestris [Mill.] Lehr.), is a typical but a minor component of the natural Mediterranean garigue, maquis and forest landscapes. Identification of the earliest domestic olives has proved to be complex. Genetic research has demonstrated that reciprocal gene flow regularly took place between wild and domesticated types ${ }^{6,7}$, while oleaster plants have served as stock material onto which cultivated clones are grafted ${ }^{8-10}$. This might partly explain why genetic studies have reached dissimilar conclusions regarding the number of domestication events and geographic origin of Olea domestication ${ }^{11-15}$.

${ }^{1}$ Zinman Institute of Archaeology, University of Haifa, Mount Carmel, Aba Khoushy Ave. 199, Mount Carmel, 3498838 Haifa, Israel. ${ }^{2}$ POB 180, 3033731 Atlit, Israel ${ }^{3}$ Leon Recanati Institute for Maritime Studies, University of Haifa, Mount Carmel, Aba Khoushy Ave. 199, Mount Carmel, 3498838 Haifa, Israel. ${ }^{4}$ Laboratory of Archaeobotany and Ancient Environments, Institute of Archaeology, and The Steinhardt Museum of Natural History, Tel Aviv University, 6997801 Tel Aviv, Israel. ${ }^{5}$ Institut Des Sciences de L'Evolution de Montpellier UMR 5554, Université de Montpellier, Place Eugène Bataillon - CC065, 34095 Montpellier Cedex 5, France. ${ }^{6}$ LIA (Laboratoire International Associé) - IRP (International Research Program) EVOLEA (INEE CNRS), Montpellier, France. ${ }^{7}$ Agricultural Research Organization, Institute of Plant Sciences, 7505101 Rishon Le Zion, Israel. ${ }^{8}$ Agricultural Research Organization, Gilat Research Center, M.P. Negev, 85280 Gilat, Israel. ${ }^{9}$ National Natural History Collections, Faculty of Life Science, The Hebrew University, E. Safra Campus, 91904 Jerusalem, Israel. ${ }^{10}$ Independent Researcher, 26 Kaplanski Street, Petah Tiqva, Israel. ${ }^{11}$ Zinman Institute of Archaeology, University of Haifa, Aba Khoushy Ave. 199, Mount Carmel, 3498838 Haifa, Israel. ${ }^{12}$ Department of Biology and Environment, Faculty of Natural Sciences, University of Haifa-Oranim, 36006 Tiv'on, Israel. ${ }^{13}$ D-REAMS Radiocarbon Dating Laboratory, Scientific Archaeology Unit, Weizmann Institute of Science, 7610001 Rehovot, Israel. ${ }^{14}$ Department of Biotechnology and Food Engineering, Technion-Israel Institute of Technology, 3200003 Haifa, Israel. ${ }^{\bowtie}$ email: galilish@netvision.net.il 


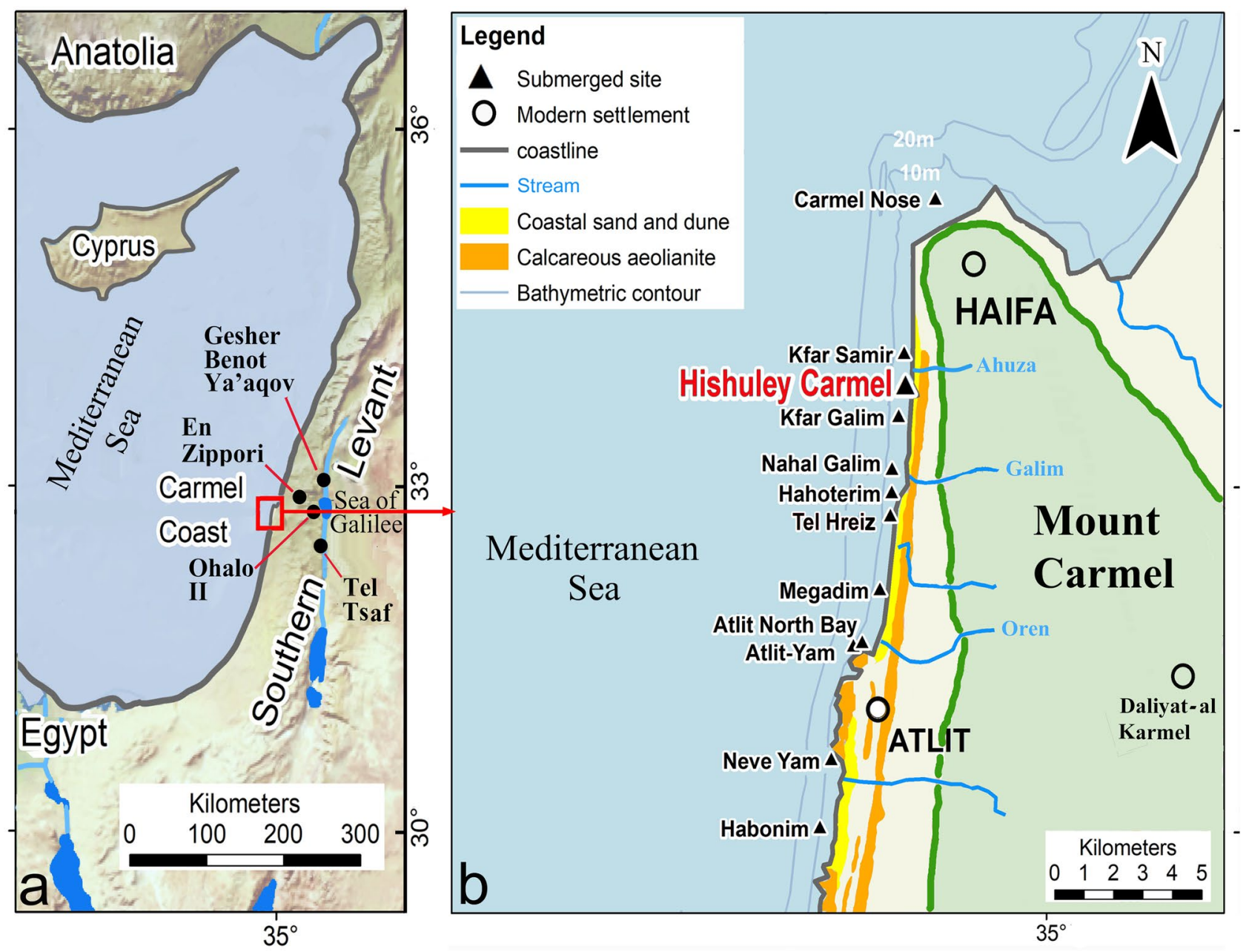

Figure 1. Location maps: (a) The Eastern Mediterranean and Southern Levant, and some sites mentioned in the text; (b) the Carmel coast and the submerged sites. Figures 1a, 1b were drawn by J. McCarthy after Natural Earth (https://www.naturalearthdata.com in the public domain). The two maps were modified by E. Galili using Adobe Photoshop CC 2018.

In the Levantine region of the Eastern Mediterranean, palynological evidence for the presence of Olea var. sylvestris goes back to the Middle Pleistocene (e.g., ${ }^{16-20}$ ). A significant increase in Olea sp. pollen grain percentages during the 7 th millennium BP has led researchers to conclude that olive cultivation first occurred in the southern Levant by $\sim 6,500$ years BP, and later dispersed to other parts of the Mediterranean Basin ${ }^{21-23}$. Remains of olive wood and/or olive pollen have been reported from many Late Pleistocene-Early Holocene Southern Levantine sites, including the 9 th millennium BP submerged site of Atlit Yam ${ }^{24}$. This was followed by a significant increase in the quantities of olive pits recovered from numerous archaeological deposits in the Southern Levant dating to 7,000 to $6,500 \mathrm{BP}^{25-31}$. Thus, both archaeobotanical finds and pollen data suggest that the initial cultivation of olives first took place in the Southern Levant no later than $\sim 6,500 \mathrm{BP}^{23,25,31,32}$.

While the earliest evidence for olive fruit processing relates to olive oil production, and dates to $\sim 7,000$ years $\mathrm{ago}^{28}$, the timing of the earliest production of table olives is currently unknown. Archaeological and written information on the consumption of table olives relates to Classical periods but the origin of the practice of debittering olives for human consumption, is as yet undated. It is assumed that in pre-Hellenistic Egypt, table olives were not available prior to Egypt's conquest of Alexander ${ }^{33}$. In his history of Greek foodways, Dalby ${ }^{34}$ wrote that the origin of preservation of olives using salt is unknown, noting that they were eaten prior to, but never during the main meal. There are written accounts that olives were part of the rations given to 5th century BC Greek mercenaries ${ }^{35}$, while André ${ }^{36}$ showed that even mythical and legendary claims for the earliest appearance of the olive in the Roman diet, date to no earlier than the 8th century BC.

The aim of this article is to present and discuss recent finds relating to table olives from a unique archaeological context in the inundated, mid-7th millennium BP site of Hishuley Carmel on the Mount Carmel coast, northern Israel (Fig. 1a,b; SI Appendix 1). The finds provide evidence for the preparation of olives for consumption, and is the earliest example known so far. Notably, they predate the historical evidence for consumption of table olives by almost four millennia. 


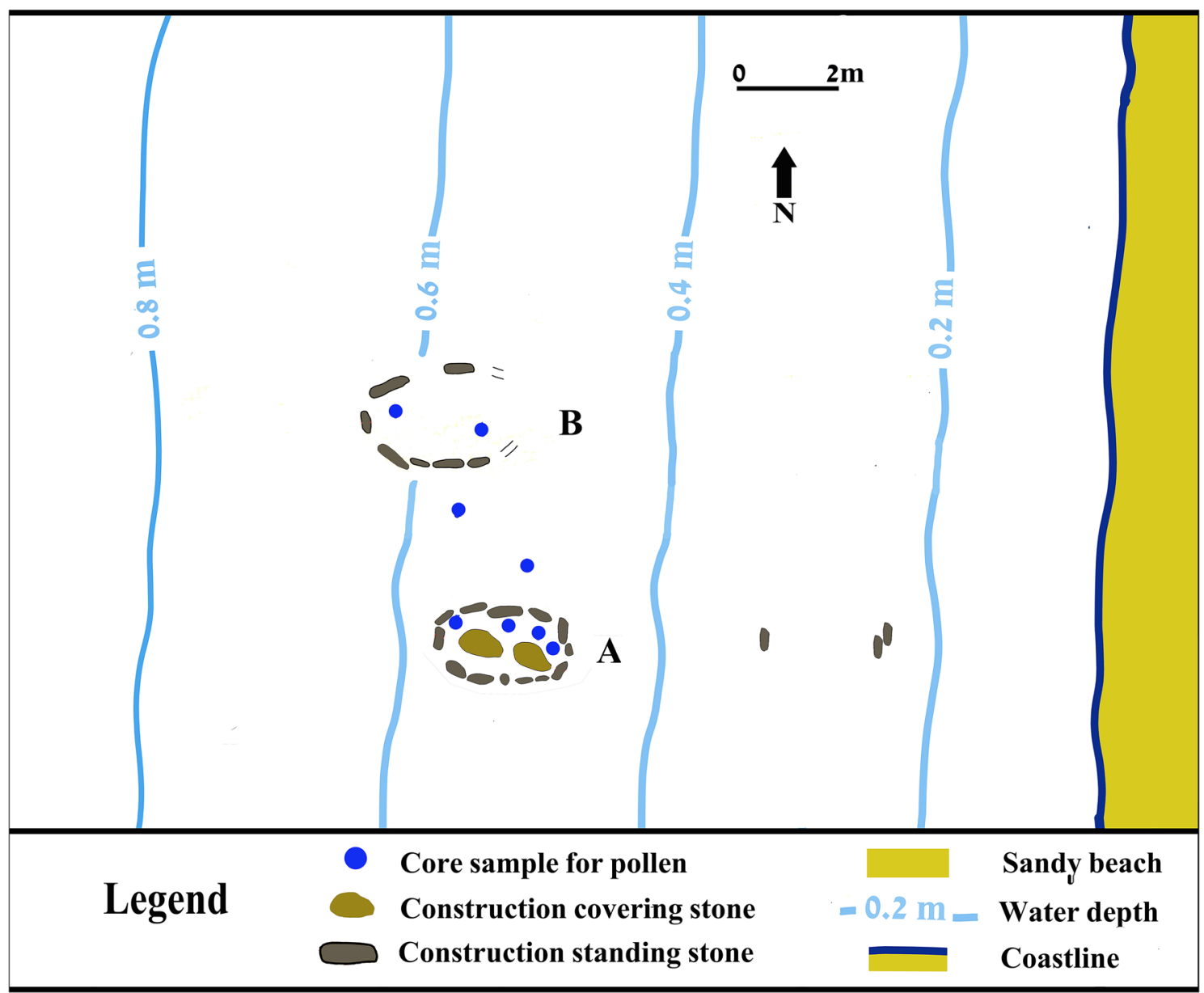

Figure 2. The site plan and layout of Structures A, B containing the olives. Water depth refers to the mean sea level during 2.2.2018, measured from the water surface to the clay paleosol surface (Drawing Ehud Galili).

\section{Material and methods}

Off the Carmel coast of northern Israel, 19 submerged Neolithic sites have been discovered that were inundated following post-glacial sea-level rise. The oldest site, Pre-Pottery Neolithic C (PPNC) Atlit Yam, is located 200-400 m offshore at water depth of 8-12 m, while a series of 18 more recent Late Pottery Neolithic/Chalcolithic (LPN/CH) sites (8th millennium BP) lie closer to shore in the inter-tidal and surf zones, at water depths of 0-7 $\mathrm{m}^{37,38}$ (see also SI Appendix 1). The sites have yielded stone-built architectural features, human burials, water wells, lithic, groundstone, bone, woven and wood objects and artefacts as well as faunal and botanical remains. The excellent conservation of the organic remains and repertoire of many unique and well-preserved architectural features (e.g. water wells, a sea wall, megaliths, cist graves ${ }^{37}$, make these sites unique and of great importance for Neolithic research in the region. Some of the sites were sedentary villages while others were temporary occupations, but all were engaged in a range of subsistence activities involving fishing and agro-pastoralism.

Underwater surveys conducted in 2011 at one of these submerged sites, Hishuley Carmel, revealed a small elliptical structure constructed of upright stone slabs and stone pavement (henceforth Structure A, Figs. 2, 3) adjacent to which were numerous olive pits ${ }^{39}$. Subsequently, a second similar-shaped installation of roughly the same proportions and also built of upright stone slabs, Structure B, was found $3 \mathrm{~m}$ to the north (Figs. 2, 4). Three further sets of standing stones, some $2.6 \mathrm{~m}$ apart, were found $\sim 2.5-4 \mathrm{~m}$ east of Structure A, and probably represent eroded remains of a third structure. In order to understand the function of the structures, we examined whether there had been any a priori selection of stone used in their construction due to their natural qualities, such as texture, porosity, strength etc. To facilitate mineralogical identification, samples were taken of 12 stones from Structures A and B, and two from the paving in Structure A (SI Appendix 2). In addition, thousands of olive pits were collected from the fill inside the two structures for dating (SI Appendixes 1, 3a-c) and for examination (SI Appendix 4). Aside from the two structures containing olive pits, four additional, round installations (up to $1.5 \mathrm{~m}$ in diameter) made of undressed stones and located $\sim 80 \mathrm{~m}$ offshore at $3 \mathrm{~m}$ depth were identified at Hishuley Carmel (SI Appendix 1: Fig. 1). These structures, perhaps the upper part of water wells or storage pits, are typical of the inundated LPN/Ch sites off the Carmel coast. No other features were recovered near the structures.

The fragmentation patterns and morphometry of the Hishuley Carmel olive pits were compared to those from the slightly earlier and neighboring inundated site of Kfar Samir, where previously early large-scale oliveoil production was identified. At Kfar Samir, high concentrations of crushed olive pits and pulp and few whole 


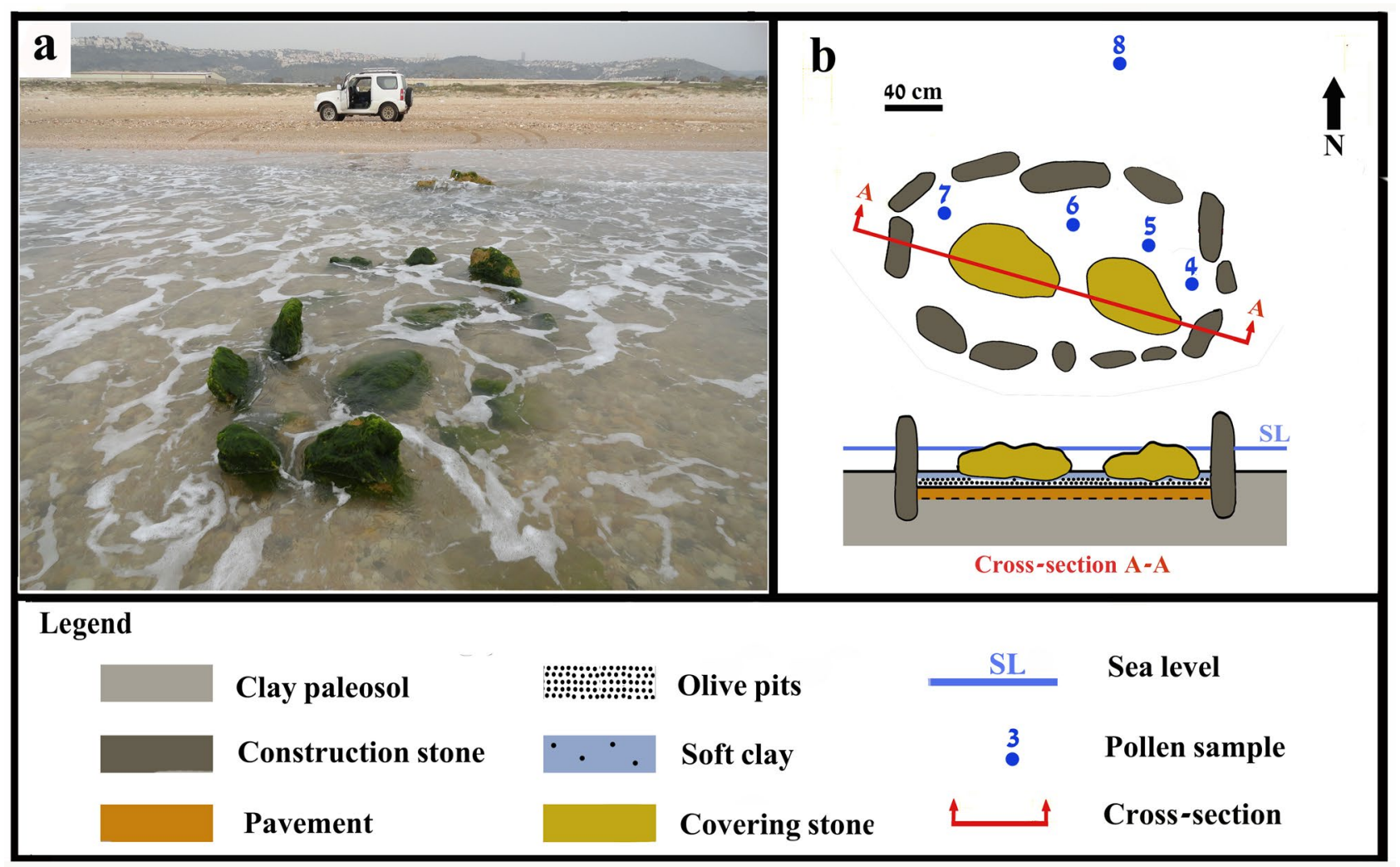

Figure 3. (a) Structure A as uncovered during 2011; (b) Plan and cross-section of Structure A (SL refers to the lowest tide during the drawing of the structure on the 2.2.2018 at $5 \mathrm{PM}$ ) (Photos and drawing Ehud Galili).

pits were recovered from an unlined round pit, dug directly into the clay paleosol, which had unworked pebbles paving at its base. The highly fragmented olive pits and the high frequency of olive pollen in the associated sediments resembled that of olive-oil extraction waste (locally termed jift in Arabic or gefet in Hebrew) recovered from a modern olive-oil processing plant on Mount Carmel (SI Appendix 5). Additionally, several large stone basins found near the pit were thought to have been used for crushing olives. Woven basket-like items recovered from another excavated pit at the site resemble traditional akals or olive oil strainers ${ }^{37}$, supporting the exploitation of olives for oil at this site.

The two archaeological olive-pit assemblages (Hishuley Carmel, and Kfar Samir) were compared in order to assess if they had served the same purpose. Fragmentation patterns were examined on a sample of 2,000 pits from both archaeological sites (Fig. 5). The pits were manually sorted and separated into: whole, halved (broken along the longitudinal suture line) and fragmented (Fig. 6). The sorted pit fractions were weighed and counted. The net weight of the whole and halved pits was calculated to compare it to the fragmented pits.

The size of the Hishuley Carmel and Kfar Samir olive pits was compared to those of modern wild/feral olive trees from Atlit and Nahal Oren on Mount Carmel and two local cultivars (Fig. 6). For the metric analysis we examined 85 and 100 whole pits from Kfar Samir and Hishuley Carmel, respectively, 100 whole pits each from two local cultivars-Barnea and Souri, and 10 pits each from naturally-growing trees in the region of Mount Carmel-six trees at Atlit ( $\left.34^{\circ} 56^{\prime} 32.2^{\prime \prime} \mathrm{E}, 32^{\circ} 41^{\prime} 34.37^{\prime \prime} \mathrm{N}\right)$, and nine trees at Nahal Oren $\left(34^{\circ} 58^{\prime} 39.31^{\prime \prime} \mathrm{E}, 32^{\circ}\right.$ $42^{\prime} 48.85^{\prime \prime} \mathrm{N}$ ) (Figs. 1b, 7).

There is extensive historical evidence for the use of sea water in curing olives [Palladius and Pliny, cited in ${ }^{36}$ ], and it is traditionally still used in some Mediterranean regions ${ }^{36,47}$. Hishuley Carmel and Kfar Samir were both coastal settlements with easy access to salt and to sea water. This spurred us to conduct experiments on the suitability of sea water for olive curing and/or storage. Fermentation experiments using sea water and sea salt were undertaken to test the effectiveness of this medium in pickling olives. Three different fermentation treatments were followed using 600 Suri olives (200 per treatment) with some olives slit and others left whole (Fig. 8). Bacterial counts, $\mathrm{pH}$ and changes in olive flesh hardness (puncture test) were monitored for each treatment (SI Appendix 6). Experiment 1: olives fermented using sea water ( 3\% salt) (Fig. 8 in yellow); Experiment 2: olives fermented using sea water $+8 \%$ sea salt (final salt concentration $\sim 11 \%$ ) (Fig. 8 in green); Experiment 3: olives fermented using tap water $+11 \% \mathrm{NaCl}$ (table salt) as a control (Fig. 8 in orange). Additionally, a pilot study of dry salting of naturally growing olives, picked on the neighbouring Atlit Ridge, was undertaken using local traditional methods (SI Appendix 6).

To further elucidate the function of the Hishuley Carmel structures, pollen analysis was undertaken of undisturbed sediments between Structures A and B, as well as samples from within each structure (SI Appendix 1). The sediments, that were collected in cores, were fully processed using standard palynological techniques and pollen grains were identified using a comparative reference collection and relevant atlases and reports (SI 


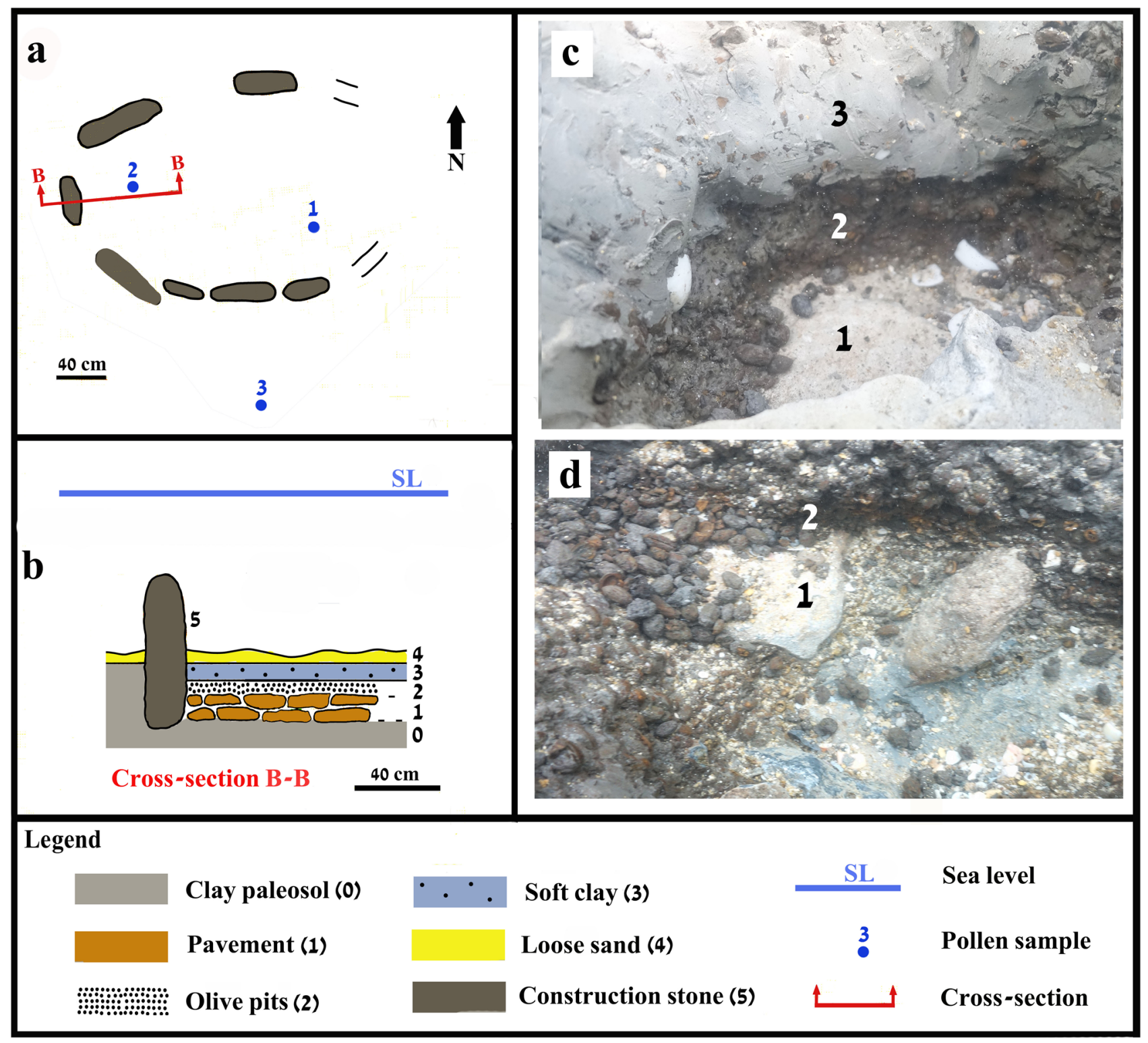

Figure 4. (a) Plan of Structure B; (b) Enlarged cross-section of Structure B and its layers (0-4); (c) Pavement (marked as 1) overlain by olive pits (marked as 2) overlain by grey, soft clay (marked as 3); (d) A close-up of the pavement (marked as 1) overlain by olive pits (marked as 2) (SL refers to the high tide during 13. 3. 2018, at 1.30 PM) (Photos and drawing Ehud Galili).

Appendix 5). The results were compared to the pollen assemblage from the olive-oil extraction waste at Kfar Samir, modern waste from olive-oil extraction, and natural pollen assemblages from fossil clay palaeosols from Kfar Samir and Hishuley Carmel sites (SI Appendix 5).

\section{Results}

The structures. When first documented, Structure A was $2.55 \mathrm{~m}$ long and $1.5 \mathrm{~m}$ wide, composed of 13 upright stones $(35-55 \times 40-60 \times 10-15 \mathrm{~cm}$ ) inserted into the clay paleosol (Fig. 3). They protruded up to $60 \mathrm{~cm}$ above it, with their tips $\sim 20-30 \mathrm{~cm}$ above sea level at low-tide (The low sea on 2.2.2018, the day of the measurements, at 17:07 pm, was 0.045 cm above the Israel Land Survey Datum, henceforth ILSD). During high tide, these stones are submerged up to $30 \mathrm{~cm}$ (the high tide during 11:16 am on 2.2.2018, the day of the measurements was $0.35 \mathrm{~m}$ above ILSD).

Two stones $(60 \times 50 \times 40 \mathrm{~cm})$ covered the structure's fill. The bottom was paved with two layers of stone slabs $(10-20 \times 10-15 \times 5-10 \mathrm{~cm})$. The structure's fill was $\sim 15-25 \mathrm{~cm}$ thick, comprising two layers of soft grey clay mixed with thousands of olive pits (Fig. 3b). Structure B comprised seven upright stones $(25-70 \times 30-70 \times 10-15 \mathrm{~cm})$ (Fig. 4). The surviving length of the structure was $\sim 220 \mathrm{~cm}$ and its width $190 \mathrm{~cm}$, though originally it was probably $260 \mathrm{~cm}$ long. The upright stones were embedded in the clay paleosol protruding up to $50 \mathrm{~cm}$ above it. The stones were submerged $30-70 \mathrm{~cm}$ during high tide. During the day of the measurements (13.3.2018) the 


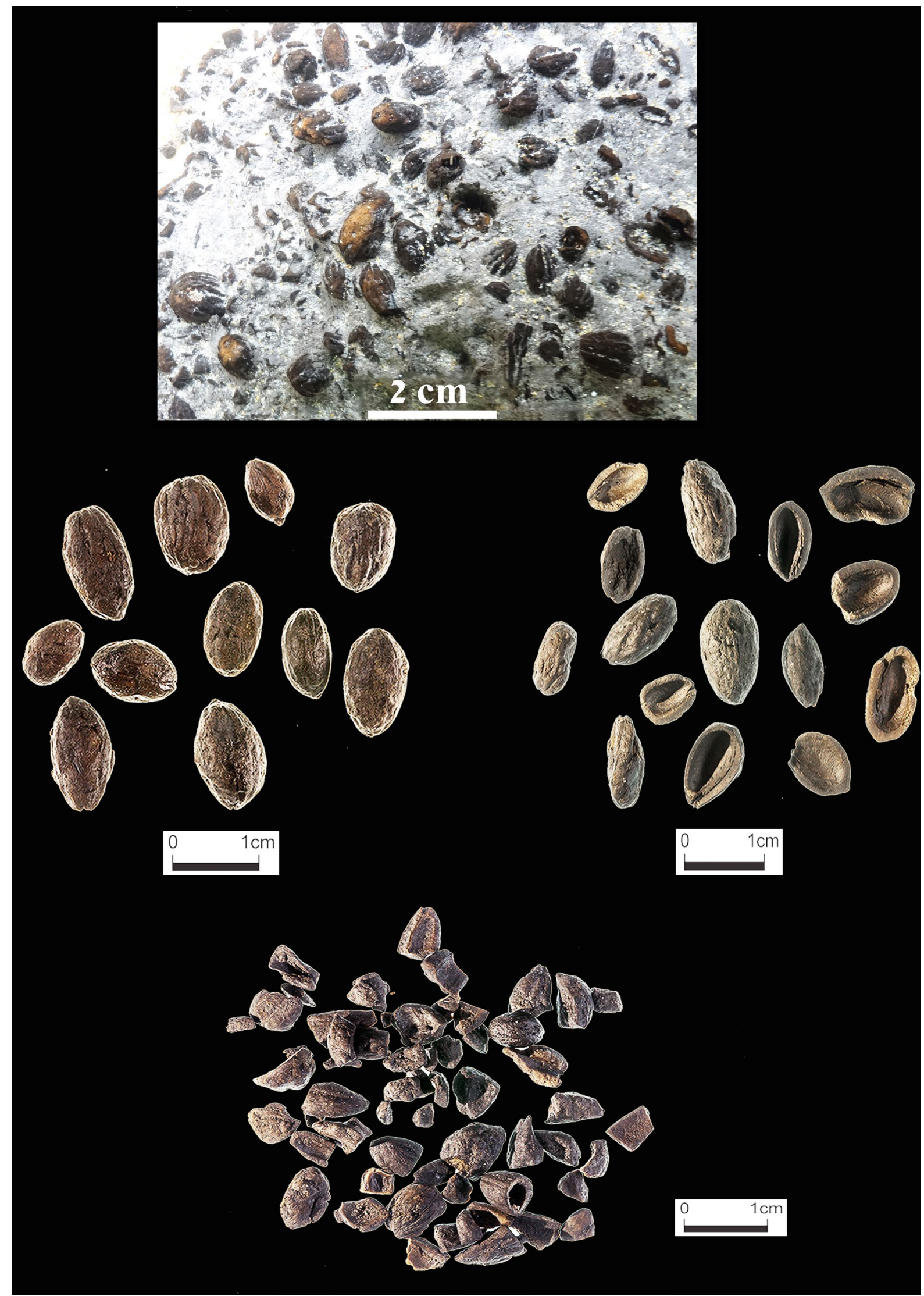

Figure 5. Olive pits from Hishuley Carmel: as found inside the Structures (top); whole (center left); whole and halves (center right); fragments (bottom) (Photos: Ehud Galili-top photo, Sasha Flit-center and bottom). 

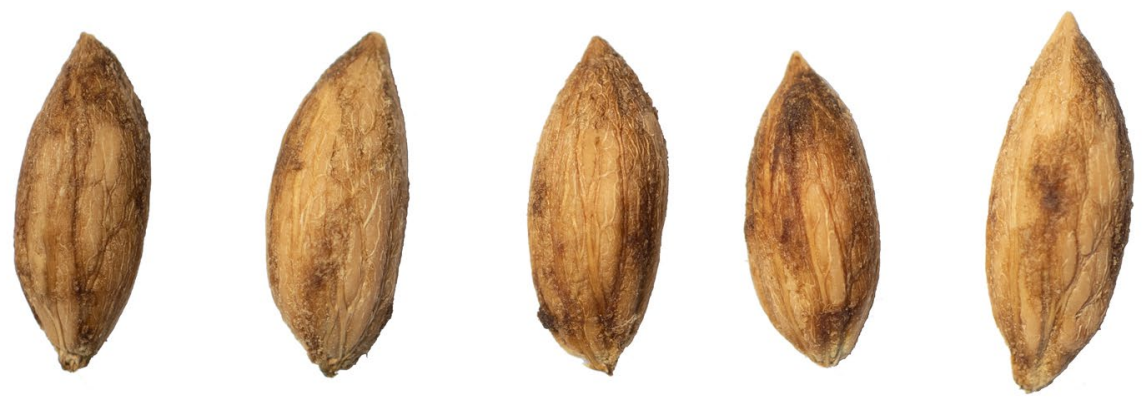

SR
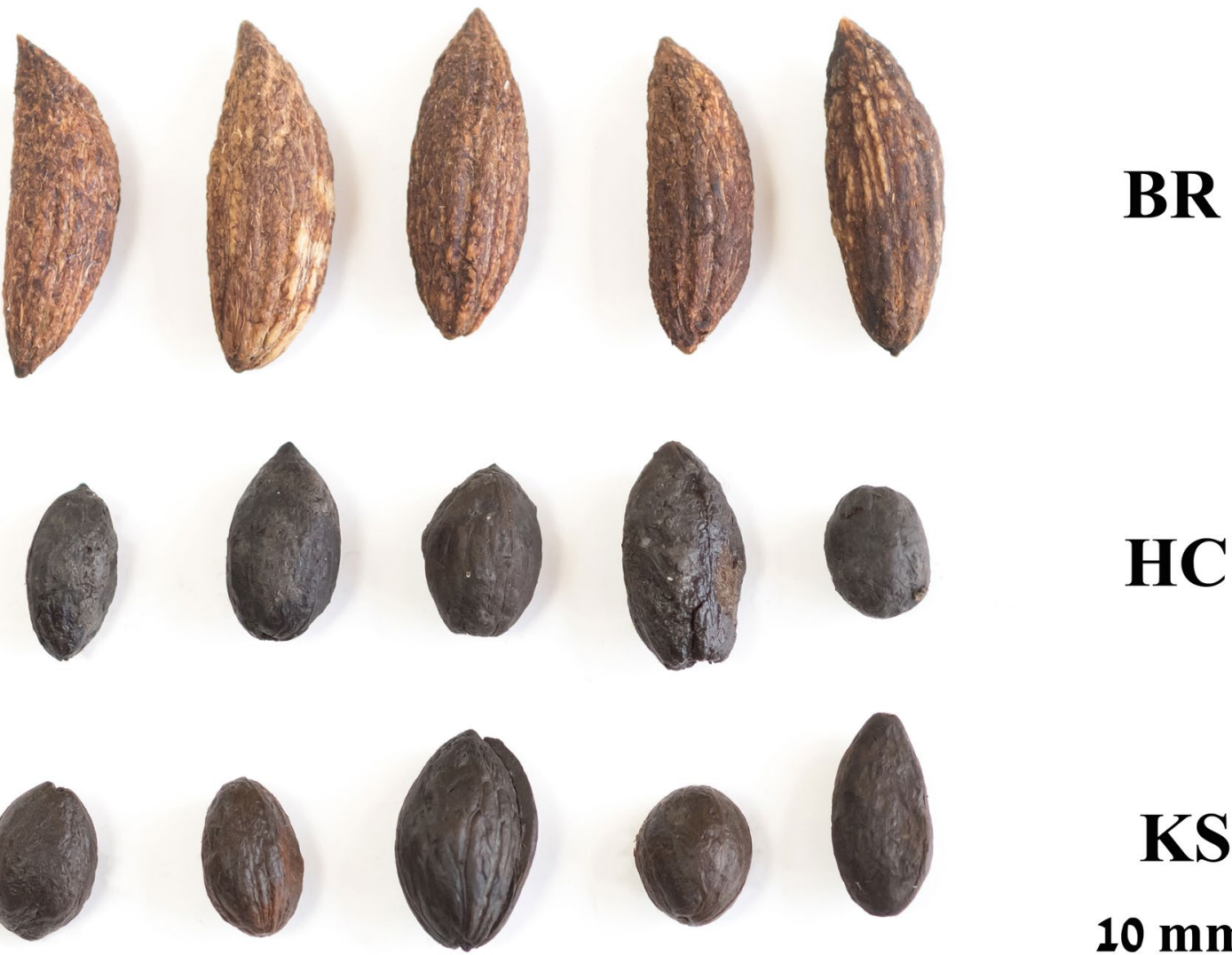

HC
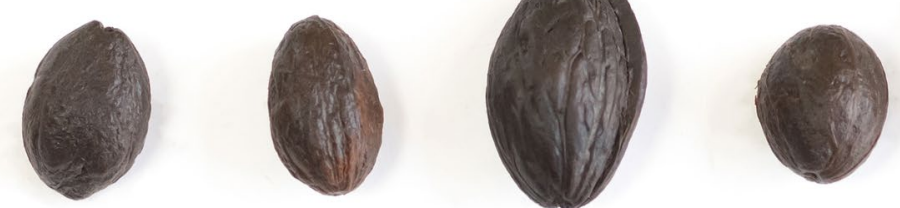

KS

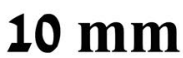

Figure 6. Representative olive pits of the reference cultivar Barnea (BR) and Souri (SR) and ancient pits from Hishuley Carmel (HC) and Kfar Samir (KS), showing the uniformity of the cultivars vs. variability in the structure and size of the archaeological olive pits (Photos: top lines-T. Nachshon-Dag,-bottom lines-O. Barazani).

high tide was $0.3 \mathrm{~m}$ above ILSD. Two layers of overlapping stones made up the bottom paving (Fig. $4 \mathrm{~b}, \mathrm{c}$ ). The fill was $\sim 15-20 \mathrm{~cm}$ thick and comprised of a dense layer of olive pits, overlain by grey soft clay with fewer pits.

Eight of the standing stones used to build the installations were kurkar (calcareous-cemented quartz sandstone of aeolian origin), two each of limestone and beachrock. One of the paving stones is kurkar and one of limestone (SI Appendix 2). All are local stones occurring within a few hundred meters of the site. Kurkar was probably quarried on the coastal ridge, limestone originated from Mount Carmel, or from the nearby Ahuza and Galim streams. The beachrock used was identified as belonging to MIS 5e (dated to 125,000-120,000 years BP) and occurs in several locations on the northern Carmel coast ${ }^{40}$.

The two structures reflect a high degree of investment in their construction. Although they were built from a variety of local stones that apparently had not been chosen for a specific natural quality, they seem to have been selected for their shape (flatness) and similar size. Moreover, the dimensions of the installations are similar and they had both been paved with stones and probabely had cover-stones. These factors imply that the structures were constructed with care to protect their contents, even though they were not air or watertight.

Olive pits from the two structures at Hishuley Carmel were dated by radiocarbon (for details see SI Appendices $3 \mathrm{a}-\mathrm{c})$. Together, the dates place the oval structures in the mid-7th millennium BP $(6,656-6,450 \mathrm{BP})$, i.e., the Middle Chalcolithic period. This makes them slightly later than the Kfar Samir olive-oil production assemblage, which was radiocarbon dated to ca. 7,000 BP (SI Appendix 3c: Fig. 1) ${ }^{37 .}$ 


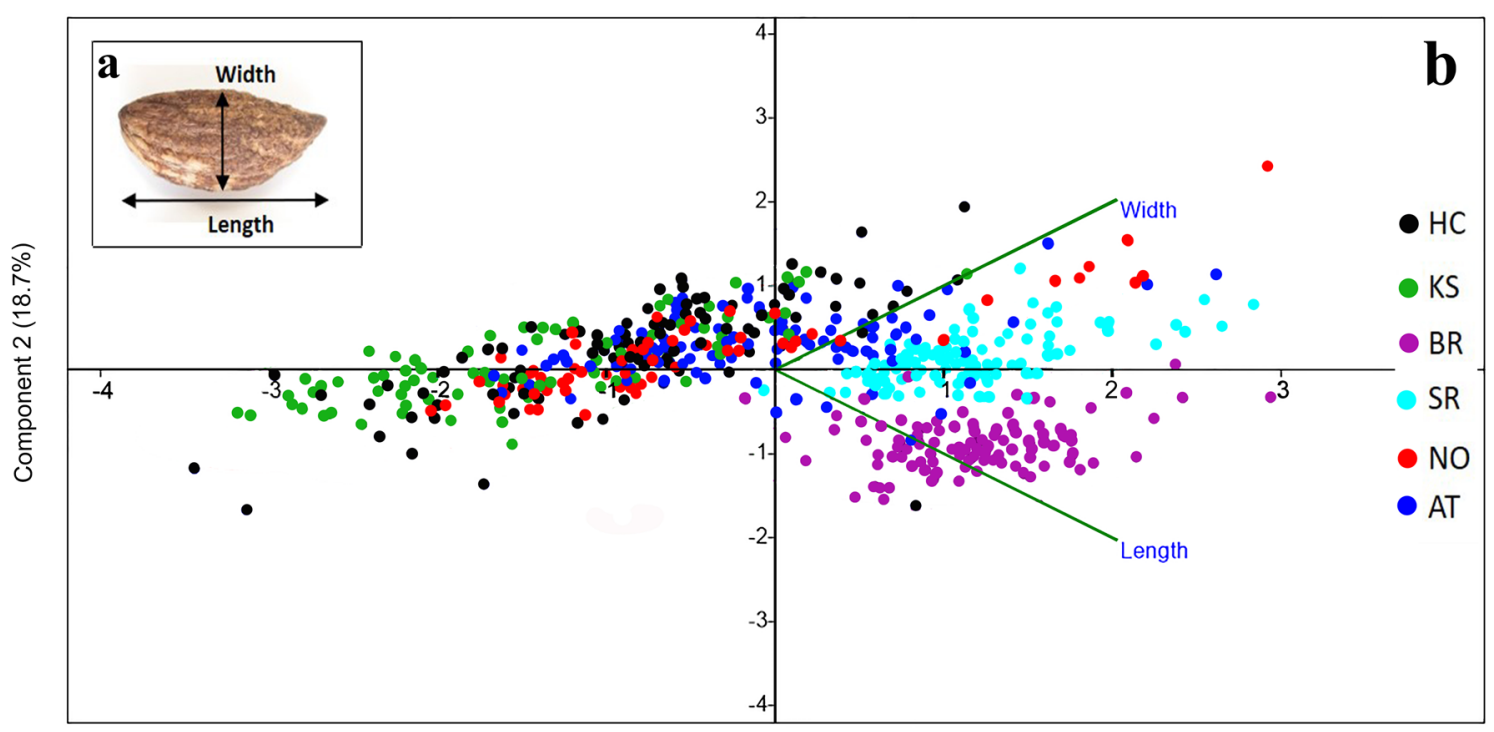

Component $1(81.3 \%)$

Figure 7. (a) Olive pit measurements taken. (b) Results of a principal component analysis (PCA) of the quantitative morphological traits: black Hishuley Carmel (HC) $\mathrm{N}=100$, green Kfar Samir (KS) $\mathrm{N}=84$, purpleBarnea (BR) $\mathrm{N}=100$, light blue-Souri (SR) $\mathrm{N}=100$, red-Nahal Oren (NO) $\mathrm{N}=89$, and dark blue-Atlit (AT) $\mathrm{N}=60$. The component 1 axis explains $81.3 \%$ of the total variation, the component 2 axis $18.7 \%$.

Olive pit fragmentation. The degree of fragmentation of the Kfar Samir and Hishuley Carmel olive pit assemblages was compared (SI Appendix 4). Both methods of data calculation (by pit weight and by counts of the absolute number of pits) gave similar results for the estimated minimum number of individual pits, the percentage of whole pits and size of the fragments (Table 1). The sample of 3,113 olive pits from Hishuley Carmel was composed of $48.0 \%$ intact pits and $52.0 \%$ fragmented while in the 5,106 pits sampled from Kfar Samir, only $15.6 \%$ were intact (both whole and halved) and $84.4 \%$ were fragmented. For fragmentation pattern 2,000 pit fragments from each of the two sites were separated out and weighed. The Hishuley Carmel fragments weigh together $46.64 \mathrm{~g}$ - an average of $23 \mathrm{mg}$ per single fragment, while the same number of fragments at Kfar Samir weighs $18.49 \mathrm{~g}$-an average of $9.2 \mathrm{mg}$ per single fragment. Thus, the olive pits from Kfar Samir are significantly more fragmented than those from Hishuley Carmel (SI Appendix 4).

Pit biometry. A principal component analysis (PCA) was used to visualize variation in the metric traits amongst the pits ${ }^{41}$. The results showed much greater size variation among the ancient olive pits of Kfar Samir, Hishuley Carmel and the living wild/feral trees of Atlit and Nahal Oren versus the reference cultivars, which are grouped closely together (Fig. 7). Furthermore, ANOVA test showed significant differences among the six groups in pit length $(\mathrm{F}=425.138, P<0.0001)$ and width $(\mathrm{F}=49.514, P<0.0001)$.

Experiment of olive fermentation in sea water. When picked, green olives are bitter and have to be cured before human consumption, with pickling in brine the most common method ${ }^{42,43}$. During debittering, in local traditional societies, olives are soaked in salt water that is changed daily for up to ten days. Afterward, they are soaked in a $10-12 \%$ salt solution to accomplish the pickling process. Lactic acid bacteria (LAB) are essential for table olive processing, since they lower the $\mathrm{pH}$ and allow long-term preservation. They are typically active in salt concentrations of $<5 \%$, and for long-term storage in up to $8 \%$ concentrations of salt ${ }^{44,45}$. Locally, the salt concentration in the brine used for curing green olives is determined by placing a raw chicken egg in water, and adding salt until the egg floats ${ }^{46}$. This practice produces brine with $\sim 10 \%$ salt, ensuring a long period of conservation (usually up to a year but sometime even longer). The pickled olives are already edible after 4-6 weeks ${ }^{46}$.

It is important to note that fermentation of table olives is not a fully predictable process. The microbiota of olives differs by olive source and cultivar and by method of fermentation (with or without alkali treatment etc.; 48,49 ). In our experiments using sea water and sea salt (SI Appendix 6), with the progress of the fermentation the enterobacteria were eliminated (Fig. 8a) and pH declined (Fig. 8b). The observed bacterial counts during fermentation with sea water were higher than in the control (tap water $+11 \% \mathrm{NaCl}$ ) (Fig. 8a). Probably, the lower salt concentration enabled the bacteria to thrive. The uncut olives with sea water $+8 \% \mathrm{NaCl}$ had significantly higher bacterial counts than the sample of cut olives kept in the same brine (Table 2, Fig. 8a). In all fermentation conditions, we obtained similar yeast counts (Table 2). According to Heperkan ${ }^{48}$, yeast plays a significant role in fermentation of olives together with LAB. Similar to our results, in a previous study ${ }^{50}$, LAB were not observed in some types of natural green olives, possibly since LAB are moderately and indirectly inhibited due to the presence of phenolic compounds, therefore, yeasts dominated. The counts of viable yeast that were reported in the literature ${ }^{48,51}$ were similar to those found by us. 

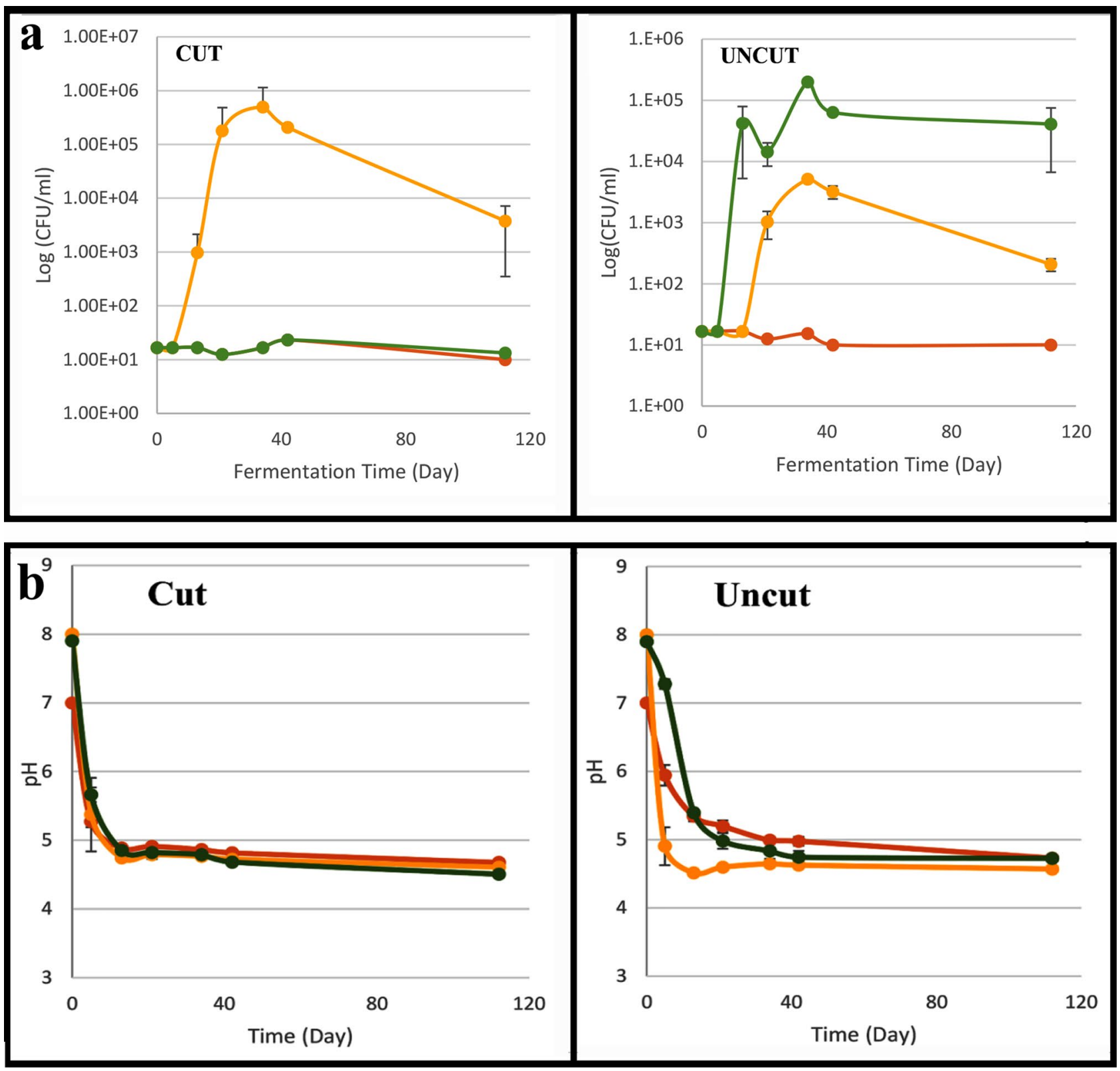

Figure 8. Results of experiments on different fermentation conditions. Red-Tap water $+11 \% \mathrm{NaCl}$; OrangeSeawater; Green-Seawater $+8 \%$ sea salt. Each point in the graphs indicates the average of three independent repetitions $(\mathrm{N}=3)$. The error bars indicate the standard deviation $(\mathrm{SD})$. When SD is smaller than the symbol, it is not visible in the graph: (a) Growth curve of total aerobic bacteria presented as $\log (\mathrm{CFU} / \mathrm{ml})$ versus fermentation time. (b) Changes in $\mathrm{pH}$ values during 112 days of fermentation. As expected, the $\mathrm{pH}$ values decreased during fermentation. The accelerated decline was observed in fermentation with seawater brine and uncut olives. (c) The alteration in Young's Modulus and Stiffness values during 60 days of fermentation. 


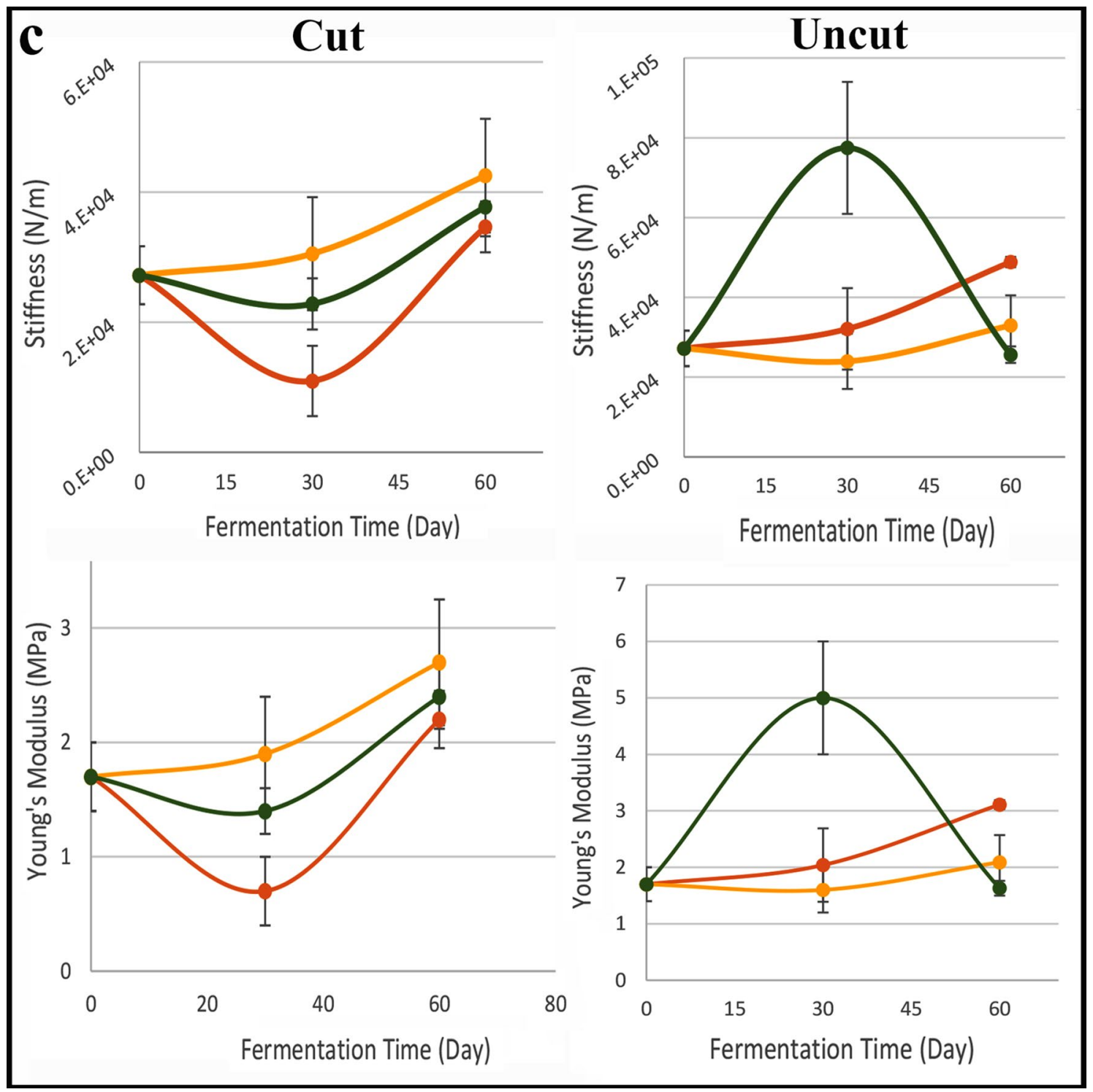

Figure 8. (continued)

In a puncture test conducted after 30 days of fermentation, no clear trend was observed in olive flesh hardness. There was no correlation between brine type and cutting and puncture test parameters (Young's Modulus, Stiffness) compared to the initial values before fermentation (Fig. 8c; SI Appendix 6). Moreover, after two months, the values were similar across all treatments. Since the use of sea water in olive fermentation gave similar values as other brines, our experiment has shown that olives can successfully be fermented using sea water. Likewise, no differences were reported by Koprivnjak et al. ${ }^{47}$ for storage of olives in brine versus sea water, before oil production.

Pickling olives with sea salt. An alternative to pickling olives with sea water prior to consumption, is to produce dry-salted table olives. This involves washing the fruit with water, mixing the washed fruit with large amounts of dry salt, followed by storing the mixture in wooden boxes or in baskets made of natural fibres or in cloth bags. Ramirez et al. ${ }^{52}$ undertook an experiment of dehydrated olive preparation by using dry-salt. They mixed the olives with salt and this mixture was kept at ambient temperature in a drum with a drainage point at the base for liquid run-off. LAB were not found and yeasts were the main microorganisms found on the olives' surface. The dry-salting process, which in this experiment took 42 to 48 days, also resulted in debittering the olives. However, a high concentration of salt has to be mixed with the olive juice in order to ensure the chemical and microbial stability of the dehydrated olive product.

We undertook a pilot experiment on $800 \mathrm{~g}$ of naturally growing olives picked during January 2020 on the Atlit Kurkar ridge using sea salt (SI Appendix 7). Boiling water was poured on the olives. They were then covered for 10 days with a $1 \mathrm{~cm}$ layer of thick, coarse sea salt, which had been collected in natural pools on the Carmel coast, and after 10 days the olives were mixed with the sea salt. The olives were edible after 20 days. Mediterranean Sea 
water contains $\sim 3.5 \%$ salt $^{53}$. Thus, for salting of dehydrated olives, sufficient quantities of salt could have been collected from small coastal pools fed with wave splash on the rocky coasts near the Hishuley Carmel site ${ }^{54}$.

Pollen analysis. Samples from both structures contained well-preserved pollen, but the olive pollen percentage was very low in both. These two samples vary in ratios and component composition, including of arboreal pollen, which may result from the olives having been picked at different locations. Yet, both samples indicate a typical Mediterranean vegetation as found today in the Mount Carmel region, and on the coastal plain in the past, comprising mainly evergreen oak (Quercus calliprinos type; notably in Structure B) and some pistachio (Pistacia sp.) and pine (Pinus halepensis) (SI Appendix 5). The relatively high oak pollen in Structure B may indicate that, in some cases, the olive fruits were gathered on the mountain, or in the coastal Kurkar region, possibly from isolated stands of this tree. Wood remains of oak and some other plants typical of both Mount Carmel and the coastal plain, before the recent deforestation, identified in the structures (SI Appendix 4) may confirm this indication. Chenopodiaeae, many of which are halophytes, are present and clearly represent the saline environment of these coastal installations. Similarly, the abundant Apiaceae pollen in the submerged fossil clay paleosols off the Mount Carmel coast, mainly of the Bunium type, characterize these coastal saline/brackish environments. These paleosols are rather poor in olive pollen, suggesting that olive trees did not grow in the immediate vicinity of the coastal sites ${ }^{55,56}$ and see SI Appendix 5. It has been shown that olive pollen is mostly abundant in soil samples derived from, or very near to, olive groves ${ }^{57}$.

The pollen from the olive-oil extraction waste ( $\mathrm{gefet} / \mathrm{jift}$ ) stands out. Samples from the pits at Kfar Samir ${ }^{28}$ are notable for their prevalence of olive pollen, between 23 and 35\%. Even higher olive pollen percentages were found in recent gefet directly collected from an active oil mill on Mount Carmel (43\%; SI Appendix 5), and are thus typical of olive-oil extraction debris. While the recent gefet's pollen spectrum represents the actual environment of the gathered fruits, the pollen spectra derived from the clay paleosols around the sites have most probably undergone mixing with additional pollen over the years. The markedly low olive pollen frequencies at Hishuley Carmel may be the result of the pollen grains having been washed away, especially if these structures were used for debittering by repeated soaking in sea water.

\section{Discussion}

The function of the Hishuley Carmel structures. In order to reconstruct the conditions under which the Hishuley Carmel structures functioned, we examined Holocene sea-level changes and coastal migration in the northern Carmel coast based on archaeological and geomorphological markers ${ }^{58}$. It is estimated that sea level was ca. 4-5 m below the current level, and that the coastline stretched some $200 \mathrm{~m}$ to the west (i.e., $\sim 180 \mathrm{~m}$ from the structures) (SI Appendix 8). Under humid conditions, such as those prevailing so close to the Mediterranean Sea, it is unlikely that uncured olives could be kept in closed installations for more than a few days. This, as freshly-harvested olives contain a considerable amount of water $\left[50-70 \%,{ }^{59}\right]$ and tend to suffer from fungal attacks or are spoiled when stored en masse without proper ventilation ${ }^{60}$. This also holds for dried salted olives. Yet, while immersed in salty sea water or mixed with salt, olive fruits could have been processed inside these sealed installations for a relatively lengthy period of time.

There is no similarity between the olive processing installations documented at Hishuley Carmel and Kfar Samir, such that it is highly unlikely that oil extraction was undertaken in the former installations. Indeed, the differences between the two in the architecture of the structures containing the olive pits, their associated material culture, the percentages of whole and halved olives and differences in patterns of olive pit fragmentation, implies that different kinds of olive processing took place at each of them. We suggest that while the Kfar Samir olives represent a typical crushed waste from olive-oil production ${ }^{28}$, the Hishuley Carmel structures were used to prepare table olives for consumption, probably by curing them in sea water or in salt. The stone-built installations would have been ideal for dry-salting since this can be done under ambient temperature. Furthermore, since the structures would not have been water-tight, liquid from the dehydrating olives could have evaporated or drained-off.

The possibility that the structures were used for storing olive oil waste, which is commonly used as fodder (e.g., ${ }^{61,62}$ ) is unlikely, as whole olive pits are not considered waste of oil extraction (see above). Moreover, the structures were close to the Neolithic coastline and were unsuitable for long-term storage of fresh olives. Ben Salem and Znaidi ${ }^{63}$ already showed that special conditions are required for long-term storage of fresh olives due to their high moisture content, thus it is unlikely that the pits recovered represent stored olives.

Wild or early cultivated trees. The radiocarbon ages, date the Hishuley Carmel structures used to prepare table olives to the first half of the 7th millennium BP, 6,700-6,500 years ago, placing them in the Middle Chalcolithic, a period that lasted some 800 years $^{64}$. Substantial architectural remains belonging to this culture were recovered for example, at the site of Tel Tsaf located in the Jordan Valley, where stone-built dwellings, a water well and round silos were recovered, as well as hundreds of charred olive pits ${ }^{65}$, and olive wood ${ }^{23}$. The data from Hishuley Carmel, Tel Tsaf and other Chalcolithic sites, including those to the east of the Jordan River ${ }^{27,32}$, then corroborate the augmented exploitation of olives at this time that is also illustrated in the regional pollen record as detailed above. The question arises whether the olives were cultivated or wild by this time?

The earliest cultivated fruit trees of the Fertile Crescent were species that required the selection of superior individuals among seedlings. Afterward, the desired genotypes were vegetatively propagated, which led to uniformity among the trees ${ }^{5}$. Thus, variation in morphological traits of fruit and pits among trees of the same cultivar are expected to be smaller than those of naturally-growing trees of their ancestors. Indeed, following other studies, Kislev ${ }^{30}$ argued that the large morphological heterogeneity of olive pits found in the Kfar Samir olive-oil processing assemblage, negated their originating from cultivated trees, as compared to wild forms, as 


\begin{tabular}{|c|c|c|c|c|c|c|c|c|c|c|}
\hline \multirow[b]{2}{*}{$\begin{array}{l}\text { Morphology } \\
\text { of pits }\end{array}$} & \multicolumn{5}{|c|}{ Hishuley Carmel } & \multicolumn{5}{|l|}{ Kfar Samir } \\
\hline & $\begin{array}{l}\text { Gross weight } \\
\text { gr }\end{array}$ & Net weight gr & $\begin{array}{l}\% \text { of net } \\
\text { weight }\end{array}$ & $\begin{array}{l}\text { Intact pits } \\
\text { (count or } \\
\text { equivalent } \\
\text { in absolute } \\
\text { numbers) }\end{array}$ & $\begin{array}{l}\text { \% of total } \\
\text { count }\end{array}$ & $\begin{array}{l}\text { Gross weight } \\
\text { gr }\end{array}$ & Net weight gr & $\begin{array}{l}\% \text { of total net } \\
\text { weight }\end{array}$ & \begin{tabular}{|l|} 
Intact pits \\
(count or \\
equivalent \\
in absolute \\
numbers)
\end{tabular} & $\begin{array}{l}\text { \% of total } \\
\text { count }\end{array}$ \\
\hline Whole pits & 396.2 & 341.7 & 44.1 & 1,363 & 43.8 & 174.6 & 128.3 & 12.7 & 661 & 12.9 \\
\hline Halved pits & 30.0 & 30.0 & 3.9 & 122 & 3.9 & 29.6 & 29.6 & 2.9 & 144 & 2.8 \\
\hline Fragments & 403.0 & 403.0 & 52.0 & 1,628 & 52.3 & 851.5 & 851.5 & 84.4 & 4,301 & 84.2 \\
\hline Total & 829.2 & 774.7 & 100 & 3,113 & 100 & $1,055.7$ & $1,009.4$ & 100 & 5,106 & 100 \\
\hline
\end{tabular}

Table 1. Characterization and fragmentation patterns of olive-pit assemblages from Hishuley Carmel and Kfar Samir.

\begin{tabular}{|l|l|l|l|l|l|}
\hline & Sample & Time 0 & After 34 days & After 42 days & After 112 days \\
\hline \multirow{3}{*}{ Uncut olives } & Tap water $+11 \% \mathrm{NaCl}$ & $1>$ & $4.47 \pm 0.01$ & $5.6 \pm 0.1$ & $4.2 \pm 0.5$ \\
\cline { 2 - 6 } & Seawater & $1>$ & $4.9 \pm 0.2$ & $4.91 \pm 0.09$ & $4.0 \pm 0.2$ \\
\cline { 2 - 6 } & Seawater $+8 \%$ sea salt & $1>$ & $6.0 \pm 0.5$ & $6.5 \pm 0.2$ & $6.2 \pm 0.5$ \\
\hline \multirow{3}{*}{ Cut olives } & Tap water $+11 \% \mathrm{NaCl}$ & $1>$ & $4.7 \pm 0.01$ & $5.6 \pm 0.2$ & $4.9 \pm 0.6$ \\
\cline { 2 - 6 } & Seawater & $1>$ & $4.9 \pm 0.6$ & $5.2 \pm 0.9$ & $4.1 \pm 0.1$ \\
\cline { 2 - 6 } & Seawater $+8 \%$ sea salt & $1>$ & $2.4 \pm 0.5$ & $4.8 \pm 0.8$ & $4.6 \pm 0.5$ \\
\hline
\end{tabular}

Table 2. Average yeast and mould counts along the fermentation in three different conditions. Values are mean $\log (\mathrm{CFU} / \mathrm{ml})$.

in cultivars, the range of variation in pit size reduces. Pit size per se is generally considered an acceptable, but not an absolute criterion, for the identification of olive cultivars versus the wild var. sylvestris ${ }^{66}$. However, it is sometimes controversial ${ }^{67}$ since for example, pits in most cultivars are significantly larger than wild types, but some modern varieties have short pits and so resemble wild populations ${ }^{68,69}$.

In our study, we found significant differences (ANOVA test) and metric variability (Fig. 7) amongst the olive pits from the inundated archaeological sites studied here as well as in the wild/feral populations when compared to pits of the two local cultivars (Figs. 5, 7). Indeed, previous results showed that the wild/feral trees we sampled, are genetically distinct from cultivated olives ${ }^{10}$. However, given the relatively late date of the Hishuley Carmel site, the distinct rise in percentages of olive pollen documented in the region at this time ${ }^{22,23}$, coupled with the morphometric variability found in the investigated ancient pits, it seems that the olives from the Hishuley Carmel and Kfar Samir sites were collected from wild trees. However, the possibility that they originated from early cultivated trees cannot be ruled out.

Summary-olive exploitation on the Carmel coast. The finds from the inundated prehistoric Carmel coast sites reveal, for the first time, a well-dated three-stage-sequence for the evolution of olive exploitation in this region:

1. At the submerged Pre-Pottery Neolithic C site of Atlit Yam ( 9,200-8,500 BP), and in earlier terrestrial sites in the region, olive trees were part of the natural vegetation $\left(\right.$ e.g. $\left.{ }^{55,56}\right)$ and were exploited as fire wood or as construction material, as attested by charred wood recovered $\left(\right.$ e.g. $\left.{ }^{24}\right)$. Notably, no olive pits were found at Atlit Yam despite careful sieving of in-situ deposits that were exceptionally rich in botanical materials with thousands of seeds, representing $\sim 90$ different plant species ${ }^{70,71}$. Given the scale, diversity and good preservation of the botanical remains at this site, it seems likely that if olive fruit was exploited on the Carmel Coast at this time, at least some traces of their remains would have been found. This leads us to conclude, that in the PPNC in this region, olive fruit was very rarely or not exploited.

2. In the Late Pottery-Neolithic/Early Chalcolithic site of Kfar Samir ( 7,500-7,000 BP), thousands of crushed olive pits, associated with stone basins and woven baskets identified as strainers, were interpreted as waste from olive-oil extraction, suggesting that olive fruits were first used for olive-oil production ${ }^{28}$. That oil production preceded table olive consumption is logical given its important role as a food (it has a much higher caloric value than that of preserved table olives; $900 \mathrm{cal} / 100 \mathrm{~g}$ versus $138 \mathrm{cal} / 100 \mathrm{~g}$ respectively $-{ }^{72}$, and as fuel for lamps and for ceremonial purposes ${ }^{73}$. The discovery of olive-oil residues in a pottery vessel from the site of 'Ain Zippori, which is contemporaneous to Kfar Samir ${ }^{28,30}$, further supports the early use of olive oil in northern Israel at this time.

3. During the subsequent Middle Chalcolithic ( 6,600 BP), based on all the factors outlined above, we provide evidence for the production of pickled or dry-salted table olives for human consumption at the site of Hishuley Carmel. This was facilitated by easy access to sea water and/or sea salt for this process. Thus, preparation 
of table olives for consumption on the Carmel coast, and possibly in other regions in the Southern Levant, post-dated olive-oil production by several centuries.

The morphometry of the whole pits from Hishuley Carmel resembles that of the slightly earlier finds from Kfar Samir. Although the latter were initially identified as belonging to wild fruits ${ }^{30}$, the new data from Hishuley Carmel combined with the pollen evidence ${ }^{22,23}$, raises the possibility that some of the olives, may have belonged to early cultivated trees.

The availability of wild olive trees on the nearby slopes of Mount Carmel and on the coastal kurkar ridges, as attested to in the regional pollen record ${ }^{55,74}$, together with the close proximity of the site to the sea (i.e., availability of sea water and salt), must have played key factors in promoting the exploitation, and perhaps cultivation, of olives at Mount Carmel coastal sites such as Hishuley Carmel. The focus on olive products may, in itself, be a reflection of the early steps in olive domestication by the first half of the 7 th millennium BP.

Received: 30 August 2020; Accepted: 23 December 2020

Published online: 26 January 2021

\section{References}

1. Boardman, J. The olive in the Mediterranean: its culture and use. Philos. Trans. R. Soc. Lond. B 275, 187-196 (1976).

2. J. P. Brun et al., L'huile d’olive en Méditerranée: Histoire, Anthropologie, Économie de l’Antiquité à nos Jours No. 2, (Institut de Recherches Méditerranéennes, Université de Provence, 1985).

3. A. Leva ed., Olive Tree in the Mediterranean Area: A Mirror of the Tradition and the Biotechnological Innovation (Nova Science Publishers, 2018).

4. Besnard, G. et al. On the origins and domestication of the olive: a review and perspectives. Ann. Bot. 121, 385-403 (2018).

5. Zohary, D. \& Spiegel-Roy, P. Beginnings of fruit growing in Old World. Science 187, 319-327 (1975).

6. Zohary, D., Hopf, M. \& Weiss, E. Domestication of Plants in the Old-World 4th edn. (Oxford University Press, Oxford, 2012).

7. Barazani, O. et al. A comparative analysis of genetic variation in rootstocks and scions of old olive trees-a window into the history of olive cultivation practices and past genetic variation. BMC Plant. Biol. 14, 146 (2014).

8. Besnard, G. et al. The complex history of the olive tree: from late Quaternary diversification of Mediterranean lineages to primary domestication in the northern Levant. Proc. R. Soc. B 280, 20122833 (2013).

9. De Candolle, A. Origin of Cultivated Plants (Kegan Paul, Trench \& Co, 1884).

10. A. Zinger, Olive Cultivation (Israel Ministry of Agriculture, 1985) in Hebrew.

11. Barazani, O. et al. Genetic variation of naturally growing olive trees in Israel: from abandoned groves to feral and wild?. BMC Plant Biol. 16, 261 (2016).

12. Besnard, G. \& Berville, A. Multiple origins for Mediterranean olive (Olea europaea L. ssp europaea) based upon mitochondrial DNA polymorphisms. C. R. Acad. Sci. III Sci. Vie 323, 173-181 (2000).

13. Besnard, G. et al. Olive domestication from structure of oleasters and cultivars using nuclear RAPDs and mitochondrial RFLPs. Genet. Sel. Evol. 33, S251-S268 (2001).

14. Breton, C. et al. The origins of the domestication of the olive tree. C R Biologie 332, 1059-1064 (2009).

15. Diez, C. M. et al. Olive domestication and diversification in the Mediterranean Basin. New Phytol. 206, 436-447 (2015).

16. Horowitz, A. The Quaternary of Israel: 230 (Academic Press, Cambridge, 1979).

17. Langgut, D., Almogi-Labin, A., Bar-Matthews, M. \& Weinstein-Evron, M. Vegetation and climate changes in the South Eastern Mediterranean during the Last Glacial-Interglacial cycle (86 ka): New marine pollen record. Quat. Sci. Rev. 30, 3960-3972 (2011).

18. Cheddadi, R. \& Khater, C. Climate change since the last glacial period in Lebanon and the presence of Mediterranean speies. Quat. Sci. Rev. 150, 146-157 (2016).

19. Chen, C. \& Litt, T. Dead Sea pollen provides new insights into the paleoenvironment of the Southern Levant during MIS 6-5. Quat. Sci. Rev. 188, 15-27 (2018).

20. Weinstein-Evron, M. The paleoecology of the Early Würm in the Hula Basin, Israel. Paléorient 9(1), 5-19 (1983).

21. Langgut, D., Lev-Yadun, S. \& Finkelstein, I. The impact of olive orchard abandonment and rehabilitation on pollen signature: an experimental approach to evaluating fossil pollen data. Ethnoarchaeology 6, 121-135 (2014).

22. U. Baruch, "Palynological evidence of human impact on the vegetation as recorded in late Holocene lake sediments in Israel" in Man's Role in the Shaping of the Eastern Mediterranean Landscape, S. Bottema, G. Entjes-Nieborg, W. van Zeist Eds. (A.A. Balkema, 1990) pp. 283-293.

23. Langgut, D. et al. The origin and spread of olive cultivation in the Mediterranean Basin: the fossil pollen evidence. Holocene 29, 902-922 (2019).

24. Caracuta, V. et al. Charred wood remains in the Natufian sequence of el-Wad terrace (Israel): new insights into the climatic, environmental and cultural changes at the end of the Pleistocene. Quat. Sci. Rev. 131, 20-32 (2016).

25. Lovell, J., Meadows, J. \& Jacobsen, G. E. Upland olive domestication in the Chalcolithic period: new $14 \mathrm{C}$ determinations from el-Khawarij (Ajlun), Jordan. Radiocarbon 52(2), 364-371 (2010).

26. Liphschitz, N., Gophna, R., Hartman, M. \& Biger, G. The beginning of olive (Olea europaea) cultivation in the Old World: a reassessment. J. Archaeol. Sci. 18, 441-453 (1991).

27. Lovell, J. Shifting subsistence patterns: some ideas about the end of the Chalcolithic in the southern Levant. Paléorient 28(1), 89-102 (2002)

28. Galili, E., Stanley, D. J., Sharvit, J. \& Weinstein-Evron, M. Evidence for earliest olive-oil production in submerged settlements off the Carmel Coast, Israel. J. Archaeol. Sci. 24, 1141-1150 (1997).

29. Salavert, A. Olive cultivation and oil production in Palestine during the Early Bronze Age (3500-2000 BC): the case of Tel Yarmouth, Israel. Veg. Hist. Archaeobot. 17, S53-S61 (2008).

30. Kislev, M. E. Wild olive endocarp at submerged Chalcolithic Kfar Samir, Haifa, Israel. J. Israel Prehist. Soc. 26, 134-145 (1995).

31. Namdar, D., Amrani, A., Getzov, N. \& Milevski, I. Olive oil storage during the fifth and sixth millennia BC at Ein Zippori, Northern Israel. Isr. J. Plant Sci. 62, 65-74 (2015).

32. R. Neef, "Introduction, development and environmental implications of olive culture: The evidence from Jordan" in Man's Role in the Shaping of the Eastern Mediterranean Landscape, S. Bottema, G. Entjes-Nieborg, W. van Zeist Eds. (A.A. Balkema, 1990) pp. 295-306.

33. Darby, W. J., Ghalioungui, P. \& Grivetti, L. The Gift of Osiris (Academic Press Incorporated, London, 1977).

34. A. Dalby, Siren Feasts: A History of Food and Gastronomy in Greece. (Routledge, 2013).

35. Xenophon, Anabasis. Carleton L. Brownson, Ed. Harvard University Press, Cambridge, MA; (1922). Online edition, Accessed January 2020 http://www.perseus.tufts.edu/hopper/text?doc=Perseus:text:1999.01.0202:book=7:chapter=1. 
36. J. André, L’alimentation et la Cuisine à Rome Vol. 66 (Belles Lettres Paria, 1981).

37. E. Galili, L.K. Horwitz, V. Eshed, B. Rosen, "Submerged Pottery Neolithic settlements off the coast of Israel: Subsistence, material culture and the development of separate burial grounds" in Under the Sea: Archaeology and Palaeolandscapes of the Continental Shelf, G. Bailey, J. Harff, D. Sakellariou Eds. (Springer, 2017) p. 111, fig. 7.5.

38. E. Galili, B. Rosen, M. Weinstein Evron, I. Hershkovitz, V. Eshed, L.K. Horwitz, "Israel: Submerged Prehistoric Sites and Settlements on the Mediterranean Coastline-The Current State of the Art" in The Archaeology of Europe's Drowned Landscapes, G. Bailey, N. Galanidou, H. Peeters, H. Jöns, M. Mennenga Eds. (Springer, Berlin 2020) pp. 443-484.

39. E. Galili, B. Rosen, Atlit Yam- preliminary report. Hadashot Archaeologiot 125 (2013). http://www.hadashot-esi.org.il.

40. Galili, E., Ronen, A., Mienis, H. \& Horwitz, L. K. Beach deposits containing Middle Paleolithic archaeological remains from northern Israel. Quat. Int. 464, 43-57 (2017).

41. Hammer, Ø., Harper, D. A. \& Ryan, P. D. PAST: paleontological statistics software package for education and data analysis. Palaeontol. Electron. 4, 9 (2001).

42. Erten, H., Boyacı-Gündüz, C. P., Ağırman, B. \& Cabaroğlu, T. Fermentation, Pickling and Turkish Table Olives. In Handbook of Vegetable Preservation and Processing (eds Ghazala, S. et al.) 209-230 (CRC Press, Boca Raton, 2016).

43. Gómez, A. H. S., García, P. G. \& Navarro, L. R. Elaboration of table olives. Grasas Aceites 57, 86-94 (2006).

44 Jacobs, M. B. (ed.) The Chemistry and Technology of Food and FoodProducts (Interscience Publishers, Geneva, 1951).

45. L. Rejano, A. Garrido. "Processing olives" in Olive Growing, D. Barranco, R. Fernandez-Escobar, L. Rallo Eds. (RIRDC Australia, 2010) pp. 649-691.

46. Brennan, G. Olives, Anchovies and Capers, The Secret Ingredients of the Mediterranean Table (Chronicle Books, San Francisco, 2011).

47. Koprivnjak, O., Procida, G. \& Zelinotti, T. Changes in the volatile components of virgin olive oil during fruit storage in aqueous media. Food Chem. 70, 377-384 (2000).

48. Heperkan, D. Microbiota of table olive fermentations and criteria of selection for their use as starters. Front. Microbiol. 4, 1-11 (2013).

49. Lucena-Padrós, H. \& Ruiz-Barba, J. L. Microbial biogeography of Spanish-style green olive fermentations in the province of Seville, Spain. Food Microbiol. 82, 259-268 (2019).

50. Alves, M., Gonçalves, T. \& Quintas, C. Microbial quality and yeast population dynamics in cracked green table olives' fermentations. Food Control 23, 363-368 (2012).

51. Tufariello, M. et al. Efficacy of yeast starters to drive and improve Picual, Manzanilla and Kalamàta table olive fermentation. J. Sci. Food Agric. 99, 2504-2512 (2019).

52. Ramirez, E. et al. Debittering of black dry-salted olives. Eur. J. Lipid. Sci. Technol. 115, 1319-1324 (2013).

53. Harvey, H. W. The Chemistry and Fertility of Sea Waters (Hildebrande Wolfe, London, 1955).

54. E. Galili, S. Arenson, Installations for Salt Production along the Carmel Coast and Galilee Coast. (Salt of the Earth, 2017).

55. Galili, E. \& Weinstein-Evron, M. Prehistory and paleoenvironments of submerged sites along the Carmel Coast of Israel. Paléorient 11(1), 37-52 (1985).

56. Weinstein-Evron, M. Biases in archaeological pollen assemblages: case studies from Israel. AASP Contribut. Ser. 29, 193-205 (1994).

57. Florenzano, A. et al. The representativeness of Olea pollen from olive groves and the Late Holocene landscape reconstruction in Central Mediterranean. Front. Earth Sci. 5, 85 (2017).

58. Galili, E., Zviely, D. \& Weinstein-Evron, M. Holocene sea-level changes and landscape evolution on the northern Carmel coast (Israel). Mediterranée 1(2), 1-8 (2005).

59. Muik, B., Lendl, B., Molina-Díaz, A. \& Pérez-Villarejo, L. Determination of oil and water content in olive pomace using near infrared and Raman spectrometry. A comparative study. Anal. Bioanal. Chem. 379, 35-41 (2004).

60. J.M. Olias, J.M. Garcia, "Olive" in Postharvest Physiology and Storage of Tropical and Subtropical Fruits, S.K. Mirta Ed. (CAB International, Wallingford, 1997) pp. 229-243.

61. Sansoucy, R. Olive By-Products for Animal Feed (FAO Animal Production and Health, Rome, 1985).

62. Molina-Alcaide, E. \& Yañez-Ruiz, D. R. Potential use of olive by-products in ruminant feeding: a review. Anim. Feed Sci. Technol. $147,247-264(2008)$

63. Ben Salem, H. \& Znaidi, I. A. Partial replacement of concentrate with tomato pulp and olive cake-based feed blocks as supplements for lambs fed wheat straw. Anim. Feed Sci. Technol. 147, 206-222 (2008).

64. Gilead, I. The chalcolithic period in the Levant. J. World Prehist. 2, 397-443 (1988).

65. Gophna, R. \& Kislev, M. Finds at Tel Tsaf (1977-1978). Revue Biblique 86(1), 112 (1979).

66. Hannachi, H. et al. Are olive cultivars distinguishable from oleaster trees based on morphology of drupes and pits, oil composition and microsatellite polymorphisms?. Acta Bot. Gallica 155, 531-545 (2008).

67 Terral, J. F. et al. Historical biogeography of olive domestication (Olea europaea L.) as revealed by geometrical morphometry applied to biological and archaeological material. J. Biogeog. 31(1), 63-77 (2004).

68. Fuller, D. Q. Long and attenuated: comparative trends in the domestication of tree fruits. Veg. Hist. Archaeobot. 27(1), 165-176 (2018).

69. Newton, C., Lorre, C., Sauvage, C., Ivorra, S. \& Terral, J. F. On the origins and spread of Olea europaea L. (olive) domestication: evidence for shape variation of olive stones at Ugarit, Late Bronze Age, Syria-a window on the Mediterranean Basin and on the westward diffusion of olive varieties. Veg. Hist. Archaeobot. 23(5), 567-575 (2014).

70. Kislev, M., Hartmann, A. \& Galili, E. Archaeobotanical and Archaeoentomological evidence from a well at Atlit-Yam indicates colder, more humid climate on the Israeli coast during the PPNC period. J. Archaeol. Sci. 31, 1301-1310 (2004).

71. Hartman-Shenkman, A., Kislev, M., Galili, E. \& Melamed, Y. Invading a new niche: obligatory weeds at Neolithic Atlit-Yam, Israel. Veg. Hist. Archaeobot. 24(24), 9-18 (2015).

72. Guggenheim, K. Y. Basic Issues of the History of Nutrition (The Magnes Press, Jerusalem, 1995).

73. Kaniewski, D. et al. Primary domestication and early uses of the emblematic olive tree: palaeobotanical, historical and molecular evidences from the Middle East. Biol. Rev. 87, 885-899 (2012).

74. Kadosh, D. et al. A Late Quaternary paleoenvironmental sequence from Dor, Carmel Coastal Plain, Israel. Palynology 28, 143-157 (2004).

\section{Acknowledgements}

The authors wish to thank the University of Haifa, the Israel Antiquities Authority and the Volcani Institute for their institutional support. The research was supported by the Honor Frost Foundation. The Israel Science Foundation Grant No. 2141/15 and the Nahum Wilbush Research Fund, ITS. The authors are indebted to A. Yurman and M. Bachar for their valuable assistance, R. Shahack-Gross and J. J. Gottlieb, from the Leon Recanati Institute for Maritime Studies, University of Haifa, for their valuable assistance and the production of thin sections; $\mathrm{H}$. Rosenstein from 'Fantasea', for providing the photography equipment; This article is the ISEM contribution $n^{\circ}$ ISEM 2020-XX. We thank the reviewers for their insightful comments that have greatly improved this paper. 


\section{Author contributions}

E. G., D.L., O.B., A.D., L.K.H., B.R., M.W-E., S.L-Y., Z.B-Z., A.F. designed research; E.G., D.L., O.B., A.D., E.K., L.K.H., I.O.R., S.C., M.W-E., Z.B-Z., A.F. performed research; E.G., D.L., O.B., A.D., I.O.R., M.W-E., Z.B-Z., A.F., E. B. analysed data; E. G., D.L., O.B., A.D., L.K.H., J.F.T., I.O.R., B.R., S.L-Y., M.W-E., Z.B-Z., A.F, E.B. contributed to the writing of the paper and the supplementary appendices.

\section{Competing interests}

The authors declare no competing interests.

\section{Additional information}

Supplementary Information The online version contains supplementary material available at https://doi. org/10.1038/s41598-020-80772-6.

Correspondence and requests for materials should be addressed to E.G.

Reprints and permissions information is available at www.nature.com/reprints.

Publisher's note Springer Nature remains neutral with regard to jurisdictional claims in published maps and institutional affiliations.

(c) (i) Open Access This article is licensed under a Creative Commons Attribution 4.0 International License, which permits use, sharing, adaptation, distribution and reproduction in any medium or format, as long as you give appropriate credit to the original author(s) and the source, provide a link to the Creative Commons licence, and indicate if changes were made. The images or other third party material in this article are included in the article's Creative Commons licence, unless indicated otherwise in a credit line to the material. If material is not included in the article's Creative Commons licence and your intended use is not permitted by statutory regulation or exceeds the permitted use, you will need to obtain permission directly from the copyright holder. To view a copy of this licence, visit http://creativecommons.org/licenses/by/4.0/.

(C) The Author(s) 2021 